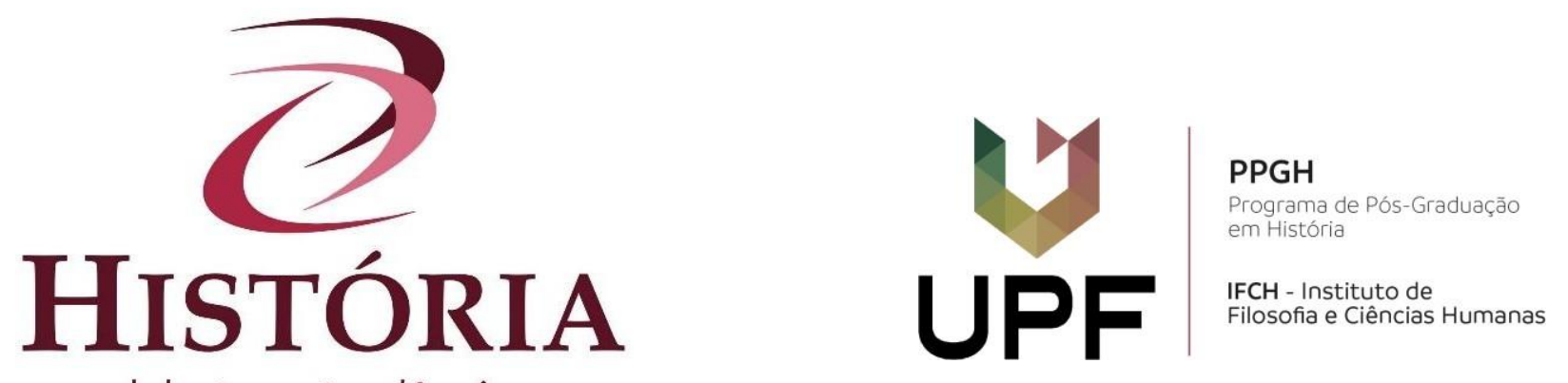

debates e tendências

\title{
Do brain drain ao exílio: apontamentos sobre emigração e radicalização política na Argentina, de Onganía a Isabel, 1966-1976
}

\author{
From brain drain to exile: notes on emigration and political \\ radicalization in Argentina, from Onganía to Isabel, 1966-1976
}

\section{Del brain drain al exilio: apuntes sobre emigración y radicalización política en la Argentina, 1966-1976}

Jorge Christian Fernández ${ }^{\mathrm{i}}$

\begin{abstract}
Resumo: Múltiplos são os fatores que levaram a expulsão de consideráveis contingentes populacionais da Argentina em direção ao exterior entre 1966 e 1976, um tempo simultaneamente marcado por crises estruturais, políticas e turbulência social. Neste sentido, o presente artigo tem por objetivo analisar processos que, embora independentes, são interrelacionados: a emigração e a radicalização política. Para tal, enfocaremos o contexto histórico do período da ditadura de 1966-1972 e o interregno democrático de 1973-1976, que antecedeu ao Golpe de 24 de março de 1976, um marco traumático da História Recente do país. Além da bibliografia especializada, utilizamos na pesquisa depoimentos orais, documentos oficiais e periódicos, o que nos permitirá uma aproximação mais fidedigna e verosímil de um passado complexo e multifacetado.
\end{abstract}

Palavras chave: Argentina. Brain drain. Exilio.

\begin{abstract}
Many factors led to the expulsion of considerable population contingents from Argentina to the outside world between 1966 and 1976, a time that was deeply marked by structural and political crisis, also social turbulence. This article aims to analyze processes that, although independent, are interrelated: emigration and political radicalization. We will focus on the historical context of the dictatorship period of 1966-1972 and the democratic interregnum of 1973-1976, which preceded the coup of March 24, 1976, a traumatic landmark in the country's recent history. In addition to the specialized bibliography, we use oral testimonies, official documents and periodicals in the research, which will allow a more reliable and credible approach to a complex and multifaceted past.
\end{abstract}

Keywords: Argentina. Brain drain. Exile.

Resumen: Son diversos los factores que llevaron a la expulsión de considerables contingentes humanos de Argentina hacia el exterior entre 1966 y 1976, un tiempo simultáneamente 
marcado por crisis estructurales, políticas y turbulencias sociales. Este artículo tiene por objetivo analizar procesos que, aunque independientes, están interrelacionados: la emigración y la radicalización política. Para ello, enfocaremos el contexto histórico del período dictatorial de 1966-1972 y el interregno democrático de 1973-1976, que antecedió al Golpe de 24 de marzo de 1976, un marco traumático de la Historia Reciente del país. Aparte de la bibliografía especializada, utilizamos en la investigación testimonios orales, documentos oficiales y periódicos, lo que nos permitirá una aproximación más fidedigna y verosímil de un pasado complejo y multifacético.

Palavras Clave: Argentina. Brain drain. Exilio.

A situação política da Argentina, tensa desde o golpe contra Juan Perón em 1955, agravouse em 1966. Em 28 de junho desse ano, o presidente eleito Illia não encontrou eco do seu solitário protesto, ao ser detido por militares em seu gabinete. Era como se o conjunto da sociedade já tivesse feito a sua escolha, sacrificando a democracia em prol de uma nova promessa autoritária. Nas palavras de Romero (2004, p. 168): Con la caída de la democracia limitada [...] las opciones se definieron y los conflictos de la sociedad [...] pudieron desplegarse plenamente.

\section{De Onganía a Lanusse: Repressão, violência e Aumento dos Fatores de Expulsão Populacional}

De início, o governo do general Juan Onganía contou com uma extensa rede de apoio vinda de quase todas as camadas sociais, desde empresariado e classes médias até os sindicalistas. Pairava na República um consenso geral de que o modelo democrático estava superado e havia esperança que este novo grupo militar levasse adiante um projeto nacional modernizador. Até parte da esquerda festejou a queda da "democracia burguesa".

Inicialmente Onganía procurou instaurar um projeto econômico desenvolvimentista, mas $\log$ o foi adquirindo um perfil liberal, graças as pressões da elite e seus tecnocratas. $\mathrm{O}$ governo era personalista e autoritário, baseado na força militar e influenciado pelos princípios da Doutrina de Segurança Nacional (DSN). Isto era traduzido na prática por repressão política e social, tanto ao peronismo revolucionário e a esquerda, como também à burocracia sindical e aos outros partidos políticos, extintos junto com o Congresso. $\mathrm{O}$ governo militar interveio com violência nas universidades, consideradas focos da "subversão comunista", cassando professores, expulsando alunos e abolindo associações estudantis. Além disso, num marco de enquadramento militar da sociedade, os militares instituíram mecanismos de censura à imprensa e impuseram medidas de cunho moralista na sociedade, ditadas pelos setores ultracatólicos.

No tocante a questão migratória, pode-se dizer que o governo Onganía foi responsável por aprofundar e acelerar o processo do brain drain, especialmente devido a sua política repressiva sobre setores da Universidade e da intelectualidade, já que acabou enviado para o exílio um substrato humano altamente qualificado, ao expulsar 1.378 professores e pesquisadores das universidades e centros de pesquisa estatal, dos quais 301 emigraram (PIGNA; SEOANE, 2006, p. 63-65). O conflito 
com o meio acadêmico iniciou-se com um decreto presidencial que abolia a autonomia acadêmica que regia as universidades desde a Reforma Universitária de 1918. Em protesto a esta violação constitucional, os estudantes e alguns docentes decidiram, em assembleia, ocupar pacificamente os claustros acadêmicos, concentrados na faculdade de Ciências Exatas, mas também na de Arquitetura. Em 29 de julho de 1966, as forças da polícia invadiram o recinto com extrema violência, destruindo o local e espancando indistintamente docentes e alunos, num episódio que ficaria registrado na história como La noche de los bastones largos, em referência aos cassetetes da polícia Segundo Pigna e Seoane (2006, p. 80), além das depurações feitas pelos golpistas, pouco tempo depois, em torno de 1.500 docentes apresentaram suas renúncias, muitos deles engrossando as fileiras da emigração. Como afirmou Liliana de Riz (2000, p. 51): "[...] muchos de ellos optaron por el exilio y la fuga de cérebros encaminó a los científicos 'indeseables' hacia los centros de estudios de Europa, Estados Unidos y América Latina".

Institutos completos, como o de Biologia Marinha, Cálculo (primeiro laboratório de computação do país), Meteorologia e o pioneiro Instituto de Televisão Educativa foram completamente desmantelados pela intervenção militar, assim também como a Editorial de la Universidad de Buenos Aires, a EUDEBA (PIGNA; SEOANE, 2006, p. 80). Um entrevistado, então pesquisador na Universidad de Buenos Aires (UBA), testemunhou a depuração feita pelos militares em 1966:

Cuando yo me "forme", me recibi, yo me fui a trabajar a la Universidad de Buenos Aires, y a los 3 o 4 meses fue la revolución de Onganía. [...] de un día para el otro [...] el grupo de investigaciones que yo estaba [...] todo el mundo se fue de la Universidad, inclusos muchos se fueron al extranjero. Y yo me quede en un inmenso laboratorio, ;solo! ${ }^{i i}$

Outra entrevistada, que havia sido docente na Universidad Nacional de Córdoba (UNC), também relembrou esses tempos do assalto à autonomia universitária e o processo que levou a emigração de centenas de pessoas eminentes:

(...) volví en el 1969 y comencé a escribir mi tesis y allí comenzó la situación política en Argentina, cuando (...) por primera vez, la policía entró en la UBA [...] y ahí fue el primer gran éxodo de profesionales argentinos y muchos del área de física. Muchos se vinieron para Brasil, otros se fueron para Estados Unidos, [...] Muchos se fueron a Venezuela. ${ }^{\text {iii }}$

Em sua memória "vivida por tabela", como diria Michel Pollak (1992), pois se encontrava fora do país quando do expurgo em 1966, evidencia-se o impacto que o evento causou e a longa duração dos seus reflexos para a comunidade acadêmica. A entrevistada incorporou à lembrança pessoal, o imaginário coletivo do grupo ao qual pertencia. Segundo Garzón-Valdez (1983, p. 196), além da UBA, o expurgo atingiu outras instituições tais como o próprio Instituto de Matemática, Astronomia e Física da UNC - onde trabalhava a entrevistada - e que em 1966 perdeu a metade de seus professores. Ao mesmo tempo, notamos na sua fala o problema dos vestígios datados de memória, pois a data precisa que ficou gravada para a entrevistada, não é a do fato em si, mas o de um evento marcante na sua vida privada, transferido inadvertidamente para a esfera pública. Evidentemente, ao não ser uma pessoa pública, suas lembranças são pautadas na história pessoal (POLLAK, 1992) 
Cabe relembrar que o êxodo profissional já havia sido iniciado bem antes, como foi visto anteriormente. Durante a primeira metade da década de 1960, o brain drain já era um fenômeno crescente, porém silencioso - ou silenciado. No entanto, o golpe dado por Onganía nos setores acadêmicos causou estardalhaço em nível nacional e internacional, já que a repressão atingiu até mesmo professores visitantes estrangeiros, que denunciaram o fato publicamente. O fenômeno do êxodo profissional, agora com contornos de exílio para alguns mais politizados, não podia mais ser negado e progrediria ainda mais. Deve-se mencionar ainda que o expurgo de Onganía, não foi tão abrangente em âmbito nacional como o seria o da ditadura de 1976.

Pouco tempo depois a "Revolução Argentina" começou a dar sinais de ruptura. As crescentes adversidades econômicas como inflação, recessão, baixos salários e desemprego se encarregariam de expulsar outro contingente populacional, visto que refletiam os desacertos das práticas liberais levadas a cabo pelo regime militar, e o acelerado desmantelamento das políticas de bem-estar social remanescentes dos tempos peronistas.

Frente a este quadro social e econômico em franco deterioro não é de estranhar que, além dos professores universitários e intelectuais, outras pessoas (geralmente de setores médios urbanos) com formação técnica ou superior, também buscassem novos horizontes fora da Argentina. Com o passar do tempo começam a migrar também autônomos e trabalhadores sem maior qualificação, evidenciando que a migração atingiu também setores da classe média baixa e da classe trabalhadora. Longe de ser apenas uma resposta individual frente a uma conjuntura política e econômica determinada, a opção pela saída do país adquiriu um caráter cada vez mais coletivo e social. De acordo com Zuccotti (1987, p. 39), por volta de 1970 o quadro da emigração era "verdadeiramente alarmante" e com tendência ao agravamento. Além dos ciclos econômicos recessivos observados em 1960, 1965 e 1970 se deve somar ainda as crises político-institucionais de 1962 e 1966. A partir de 1969 a 1970 acrescente-se a este complexo quadro conjuntural o influxo do crescimento da violência institucional e do nascimento da violência guerrilheira.

A crescente oposição ao regime de Onganía culminou num levante popular espontâneo ocorrido no enclave industrial e estudantil de Córdoba, em 29 de maio de 1969, o qual passaria a ser conhecido por Cordobazo. Durante dias, populares desafiaram a autoridade governamental, colocando em xeque a sua capacidade de manter a "ordem”, seu único capital político. O levante significou o início de um processo de radicalização social que se estenderia até 1975, no qual os setores subalternos (principalmente o operariado e os estudantes) teriam um papel fundamental, pautando seu acionar em função da identificação do inimigo a ser combatido: o poder militar autoritário, considerado "testa-de-ferro" do grande capital (ROMERO, 2006, p. 176). Estudante de Psicologia durante o período, Hilda G. relembrou e explicou um pouco da sua atuação na política estudantil. Tal como milhares de jovens, ela percorreu um intenso caminho de conscientização e radicalização política: 
¡En Sicología [...] era un "fervo" de actividad política terrible! [...] en la intervención en la Universidad se armaron los NURES, que eran los Núcleos de Resistencia a la Intervención [...] En una de esas actividades conocí a Bruno, que era medio como un líder, de los que subían y discursaban...ahí entonces si comencé a leer materiales [...] de volantes, libros, y Marx, y Engels [...] iY militábamos como locos! [...] todos los momentos que había los utilizábamos [...] para los actos relámpago, volanteos, pintábamos, hacíamos de todo [...] ipero estábamos convictos de lo que hacíamos! iv

Além da situação interna, o próprio contexto internacional favorecia a radicalização e a polarização política: a permanência e sucesso dos exemplos cubano e chinês, o Maio francês, os distúrbios contra a guerra no Vietnã, etc. Na América Latina, entendia-se que o poder autoritário vinha do "imperialismo norte-americano", representado por seus agentes e sócios nos governos locais. Contra eles se dirigiriam os esforços dos movimentos armados de esquerda. O Cordobazo marcou também uma união e confluência entre a base operária e os estudantes nunca antes vista. Hilda rememorou sua participação num dos tantos grupos que justamente intentavam dar coesão a esta integração política:

En esas actividades estudiantiles me vinculé con un grupo trotskista y entonces
trabajábamos en el Frente Obrero Estudiantil (FOE) (...) en las huelgas y los paros, habían
actividades del grupo estudiantil con el frente obrero (...) volanteos, pintadas y ese tipo de
actividades (...)Yo estaba destruida: porque me levantaba a trabajar, estudiaba, estaba en
el FOE, volanteábamos hasta las 3-4 de la mañana (...) corrimos mil veces (da polícia),
aprendimos a "chutar" las bombas lacrimógenas, tirar cócteles molotov, jtodo eso que los
jóvenes aprendimos a hacer!

Estas aproximações e contatos possibilitaram gradativamente o surgimento dos grupos guerrilheiros, marxistas ou peronistas, todos pretendendo tornar-se a vanguarda de um processo revolucionário à imagem de Che Guevara. O peronismo, ainda proibido, estava presente no imaginário político como a autêntica resistência ao imperialismo e com uma longa tradição de lutas atraiu jovens da classe média criados no vácuo do antiperonismo. Deve-se destacar que a ambiguidade de Perón permitia várias interpretações por parte de seus seguidores, muitas delas conflitivas e antagônicas. Assim, grupos jovens, oriundos do nacionalismo católico, da esquerda marxista ou da Igreja de Terceiro Mundo - corrente eclesiástica em voga, identificada com os pobres - concordavam ao identificar o peronismo como uma expressão popular e libertadora.

Entre meados das décadas de 1960 e 1970 surgiram diversos grupos armados de esquerda na Argentina. A partir das diversas linhas do marxismo surgiram correntes revolucionárias que foram se constituindo em organizações guerrilheiras. Assim, inspirados no foquismo guevarista surgiram as Fuerzas Armadas de Liberación (FAL); das cisões maoístas do ortodoxo Partido Comunista Argentino (PCA) surgiu a Organización Comunista Poder Obrero (OCPO) e o Partido Comunista Revolucionário (PCR); e do Partido Revolucionario de los Trabajadores (PRT), originalmente de linha trotskista, nasceu o Ejército Revolucionario del Pueblo (ERP) que se tornaria posteriormente a mais importante organização armada guevarista. Da esquerda peronista emergiram “formações especiais" como as Fuerzas Armadas Revolucionárias (FAR), as Fuerzas Armadas Peronistas (FAP) e os Descamisados. No entanto, a mais importante delas surgiria em 1970, englobando os outros grupos menores e se tornando uma poderosa organização cujo objetivo imediato consistia no retorno de Perón ao poder, para assim poder dar continuidade ao processo 
revolucionário que construiria o "socialismo nacional", a organização montoneros.

Seus métodos consistiam na chamada "ação direta", empregando a violência como instrumento da política. A primeira ação de envergadura dos montoneros, em 29 de maio de 1970, foi carregada de revanchismo e profundo simbolismo: o sequestro e posterior execução do general Pedro Aramburu, ex-presidente de facto, artífice do golpe de 1955 que derrubou Perón e responsável pelos fuzilamentos de peronistas em 1956. A data era duplamente provocativa, pois além de ser o Dia del Ejército, também relembrava um ano da explosão social do Cordobazo (GILLESPIE, 1998, p. 120). Aos poucos se seguiram atentados, ocupações armadas de povoados, fábricas e quartéis, e também “expropriações”, sequestros, execuções de "inimigos de classe" (militares, empresários, etc.). Aos poucos a guerrilha urbana foi crescendo como opção de luta no vácuo deixado pela prática política, desabonando paralelamente qualquer manifestação política conciliadora ou mesmo uma saída política democrática para pôr fim ao regime militar.

De fato, nenhum dos grupos guerrilheiros soube traduzir em projeto político um futuro para o país, alguns por considerar Perón a solução para todos os males e outros por acreditarem que a luta armada era o processo revolucionário em si e a violência uma parte integral da solução (DE RIZ, 2000. p.77). Assim, para uma importante parcela da população a violência guerrilheira parecia justificada e referendada pela presença da violência do Estado nas mãos dos militares. Portanto, a "Revolução Argentina" de Onganía, que deveria durar até o ano 2000, não suportou o peso das reivindicações da população, acossada tanto pela política econômica quanto pela falta de liberdade e perspectivas. O ditador Onganía foi deposto pelos próprios colegas de armas, ainda em junho. Assumiu Levingston, militar da corrente nacionalista e vagamente populista, procurou apoio em líderes políticos de segunda linha para levar a cabo seu projeto de governo, o qual além de não encontrar eco popular na proposta ainda irritou as elites, setores liberais das forças armadas e as corporações transnacionais. Entretanto, o que precipitou sua queda, tal como a de Onganía, foi um novo levante popular em Córdoba, em fevereiro de 1971, onde houve presença ostensiva das forças guerrilheiras. Mais uma vez, a questão da ruptura da segurança coletiva do sistema colocava o governo em xeque. Restava à junta militar uma última cartada, o general Lanusse.

Embora antiperonista ferrenho, Lanusse havia chegado à conclusão que o peronismo era uma realidade e que sem Perón a paz e o pacto social pareciam impossíveis. Politicamente mais hábil que seus antecessores, tinha plena consciência da necessidade de uma saída institucional para a crise do regime militar concertando um "Grande Acordo Nacional" que permitiria a abertura política, a legalização dos partidos e garantiria eleições, nas quais pretendia apresentar-se como candidato de transição. Contudo, deveria contar com 
apoio dos políticos de diversos matizes, mas em especial de Perón, esperando que este contivesse as organizações armadas em troca de benefícios políticos e pessoais.

Perón oscilava entre a pacificação e a provocação, incitando os setores armados da juventude peronista, cujas ações se multiplicavam fustigando o governo, que reagia com maior violência. Apesar de ser naturalmente ilegítimo, o regime pretendia mascarar suas manobras repressivas com um verniz de institucionalidade, pela criação de um tribunal especial anti-subversivo, o chamado Camarón, e de modificações no código penal para enquadrar os exclusivamente guerrilheiros. Mas continuavam as detenções sem julgamento prévio, a tortura sistematizada e a violação dos direitos humanos. Conforme Duhalde, durante o governo de Lanusse a aplicabilidade da violência institucional paralela e em oposição às normas vigentes do Estado de direito alcançaram um ápice:

[...] aparece la metodologia de la desaparición con el sentido que adquirirá masivamente después del golpe del '76. Es decir, secuestrar para hacer desaparecer. [...] Secuestrar para torturar, extraer información y luego matar (1999, p. 39-40).

Todavia, o pior estava por vir. Em 22 de agosto de 1972, dezesseis líderes guerrilheiros das FAR, montoneros e do ERP presos em uma base naval, foram executados a sangue frio pelos militares da Marinha sob alegação falaciosa de uma tentativa de fuga (ANGUITA; CAPARRÓS, 2006, p. 576-578). O acontecimento veio a público como o "massacre de Trelew", acirrando ainda mais os ânimos populares contra o regime e incentivando a escalada de violência guerrilheira. Segundo Duhalde (1999, p. 40-41), o acontecido em Trelew prova que as forças armadas argentinas já haviam assumido o Terrorismo de Estado (TDE) como metodologia repressiva quatro anos antes do golpe de 1976. Tal como um laboratório, o massacre de Trelew continha, em pequenas dimensões, as características básicas do que se aplicaria posteriormente em grande escala: o aniquilamento dos dissidentes, a "pedagogia do terror" para re-estabelecer a autoridade, o falseamento ou a negação da autoria dos crimes, o "pacto de sangue" que envolvia o conjunto das forças armadas e a aplicação da "lei de fuga" como pretexto para justificar os assassinatos.

Se o panorama político era pouco alentador, o panorama econômico não diferia. Os indicadores econômicos sinalizavam um quadro de crise em desenvolvimento. Na virada de 1972, a inflação chegou a atingir 34,7 \%, quase triplicando a inflação do ano 1970 (ANGUITA; CAPARRÓS, 2006, p. 459). A produção entrava em desaceleração e recessão, a queda na produção pecuária e agrícola levou a uma alta nos preços, que o governo tentava controlar mediante tabelamento de preços e aumentos salariais, mas sem sucesso por causa da espiral inflacionária. Zuccotti descreveu o cenário de 1972: 
millón de parados forzosos. [...] Quiebra de la empresa privada. Vaciamientos y desnacionalizaciones. La producción en acentuada baja. [...] Los monopolios nacionales y foráneos desangrando al pueblo. La república sin gobierno (1987, p. 40-41).

Evidentemente que este contexto potencializava a emissão demográfica, embora de um modo geral os fatores de "expulsão" e de "atração" se mantivessem em certo equilíbrio até meados da década de 1970, excetuando-se os períodos de maior intolerância política: 1952-1955, 1955-1958, 1962, 1966-1972 (GARZÓN-VALDEZ, 1983, p. 185). Além da já notória fuga de cérebros, agora cada vez mais pessoas "fugiam" da Argentina, como pequenos comerciantes e industriais, técnicos de nível médio e operários com ou sem qualificação. O perfil urbano se mantinha. O país que ainda exercia o maior fator de atração era os Estados Unidos (ZUCCOTTI, 1987, p. 40).

Paradoxalmente, o país continuava a receber migrantes internos e dos países limítrofes, verdadeiros foragidos da miséria de seus locais de origem. Por esta época, houve um sensível acréscimo de cidadãos chilenos (55.917 registrados entre 1970 e 1974) e uruguaios (54.627 registrados entre 1970 e 1974), e deve se destacar que alguns destes vinham com motivação política (LATTES; OTEIZA, 1987, p. 46). Com o progressivo estancamento do processo de desenvolvimento econômico argentino, estes contingentes populacionais foram diretamente afetados, passando da pobreza estrutural para a miséria e a marginalização, tornando-se cada vez mais membros indesejados e, portanto, excluídos da sociedade habitando nos cinturões que germinavam em torno das cidades.

Para fins de 1972, o projeto político de Lanusse estava fracassado. Teve ainda uma longa e desgastante negociação com Perón pela transição democrática. Lanusse ainda conseguiu neutralizar a candidatura de Perón a presidência, todavia, a custas da sua própria candidatura. O peronismo escolheu Héctor Cámpora, secretário de Perón e ligado à esquerda do movimento como candidato às eleições de março de 1973. O lema da campanha não ocultava a manobra política e a fictícia representatividade do candidato indicado: "Cámpora al gobierno, Perón al poder” (ROMERO, 2004, p. 189).

\section{De Cámpora à Isabel: violência política e exílios}

Após a vitória eleitoral e a festa popular na posse de Cámpora, em 25 de maio de 1973, faltava somente o retorno do velho líder para concluir o ciclo interrompido em 1955. Para os jovens revolucionários parecia haver chegado o momento do "socialismo nacional" de Perón. Um entrevistado explicou porque se distanciou do trotskismo em que militava para somar-se a corrente revolucionaria peronista:

Yo no estaba con las tesis foquistas, sino con las insurreccionalistas, entonces las de la Juventud Peronista. [...] Yo consideraba que la única revolución posible era con un movimiento social en acción [...] Por eso me quedé con montoneros, que fue inclinándose 
cada vez más a la izquierda, y la consigna que me convenció a mi fue cuando la elección de Cámpora: ;Qué lindo, que lindo, que lindo que va a ser! ;Un hospital de niños el Sheraton Hotel! vi

Percebe-se no depoimento que, além do racional, a sua motivação também possuía raízes profundas, calcadas talvez no imaginário coletivo que idealizava o peronismo das décadas de 1940 e 1950, assim como no apelo popular e a mística presente em torno do peronismo. Sem falar na peculiar leitura do fenômeno peronista feita pelos setores da juventude radicalizada e incentivada pelo próprio Péron no exílio. Ou seja, o peronismo visto como uma experiência histórica anti-imperialista e anti-oligárquica cerceada pela força militar, cujos únicos e legítimos herdeiros seriam a organização montoneros.

Evidentemente, longe de ser um movimento coeso, o peronismo era um conglomerado político com interesses muito diversos e díspares, embora todos cultuassem a mesma figura. Para os operários peronistas da velha guarda, Perón era o líder paternal que reinstalaria as benesses do Estado benfeitor dos tempos idos. Para a extrema direita peronista, ele era o caudilho militar que implantaria a ordem e a segurança, expulsando os “infiltrados marxistas" do movimento. A questão era a seguinte: qual papel Perón representaria efetivamente no seu retorno ao cenário político?

Mas os acontecimentos atropelaram o governo de Cámpora, precipitando-o. Já na noite da posse, enquanto os militares eram "expulsos” da Praça de Maio pela população, outra multidão forçou a libertação dos presos políticos no presídio de Villa Devoto, levando o novo governo a assinar um decreto de anistia para salvar a institucionalidade. Cabe destacar que, apesar das aparências, o governo de Cámpora não foi apenas um interregno para o retorno de Perón: se constituiu também em um espaço onde a esquerda peronista pode ocupar algumas importantes posições no governo, seja nos ministérios ou nos governos provinciais. Também a atividade social e política foram intensas. Nesse período proliferaram ocupações de fábricas, repartições públicas e empresas por parte de seus empregados. Conforme Anguita e Caparrós (2006, p. 72-73), essas ocupações tinham diversas finalidades, como por exemplo, extinguir o continuísmo da ditadura no serviço público, já que muitos de seus ex-funcionários estavam ainda em seus cargos. Mas o primordial era a luta e a pressão pela obtenção de melhorias concretas para a classe trabalhadora num governo democrático e popular. Outra questão importante, especialmente para as múltiplas facções do peronismo, era ganhar espaços dentro do próprio governo. Logicamente que esta agitação política foi percebida como uma situação pré-revolucionária que, se por um lado, extasiava os setores revolucionários, pelo outro, trazia à tona o velho fantasma do comunismo que tanto atemorizava a burguesia.

Contudo, a inflexão do camporismo se daria com o episódio de Ezeiza. Em 20 de 
junho de 1973, uma multidão de aproximadamente dois milhões de pessoas aguardava no aeroporto internacional de Ezeiza a volta de Perón. Porém, a festa transformou-se em tragédia quando a equipe da segurança do palco onde Perón discursaria - formada por grupos de direita - abriu fogo contra a massa de jovens militantes da esquerda peronista que vinha saudar o seu chefe. Pode-se ter uma ideia do impacto provocado por este trágico acontecimento, a partir da evocação desta entrevistada: Hasta hoy, cuando llega el avión a Ezeiza... ;Yo solo pienso en el masacre que fue cuando Perón llegó! vii

A massacre de Ezeiza demonstrou a extrema polarização do movimento peronista ao público e foi dissipando na sociedade as expectativas de ver em Perón um líder pacificador ou mediador de conflitos. Pressionado por Perón, Cámpora renunciou pouco tempo depois (julho de 1973) em favor de novas eleições que, finalmente, empossaram Perón como presidente e sua esposa, Isabel, como vice. No séquito íntimo do general apenas apareciam notórios personagens da extrema-direita peronista, como Lopez Rega. O octagenário líder havia finalmente definido a escolha do seu papel. No plano social e econômico a ruptura já se evidenciava em termos da defasagem entre o reformismo reciclado pelo general Perón e a ideia revolucionaria pretendida pela sua jovem ala esquerda.

A queda de Cámpora significou o fim dos setores revolucionários do peronismo. Gradativamente, os seus espaços no governo foram caindo nas mãos da direita. Assim, logo chegaria a vez dos governadores, ministros e demais funcionários próximos à "Tendência" e que foram exonerados de seus cargos por meio de artifícios legais, como a chamada Ley de Prescindibilidad, que permitiu a demissão de servidores considerados suspeitos de "ligações subversivas" (GASPARINI, 2005, p. 65). As províncias de Buenos Aires e Córdoba foram as mais atingidas pelos expurgos: Oscar Bidegain, o governador bonaerense foi obrigado a renunciar, sendo substituído pelo seu vice Victório Calabró, de linha ortodoxa. Já em Córdoba, o coronel Navarro, chefe de Polícia, prendeu o governador Obregón Cano e o vice Atílio Lopez. Depois Perón chancelou a manobra golpista ao decretar a intervenção na província (SAENZ QUESADA, 2003, p. 151).

Prontamente, a repressão política também chegou às universidades, último reduto dos setores revolucionários do peronismo. Em agosto de 1974, o novo ministro de Educação, Oscar Ivanissevich, nomeou notórios fascistas para comandar as universidades, cuja "missão" consistia em "purificar" os recintos acadêmicos do marxismo (GILLESPIE, 1998, p.195-196). O processo se desenrolou nas diversas universidades federais e houve a expulsão de todos os indivíduos ligados principalmente à "Tendência Revolucionária". Todavia, mesmo que dirigidos inicialmente aos considerados "infiltrados marxistas" no 
peronismo, os expurgos e as perseguições atingiram todos os esquerdistas.

Logo, os choques entre os extremos do movimento e o desgaste contínuo entre Perón e a esquerda peronista levou a ruptura final dentro do peronismo ocorrida em primeiro de maio de 1974, quando Perón foi abandonado pelos montoneros após um discurso onde o líder insultou a ala revolucionária do partido. Um antigo militante da Juventude Peronista (JP) não somente relembra a data fatídica, como também brinda a sua particular leitura da querela interna do peronismo:

Entonces yo estuve el primer de mayo (de 1974). Que fue un masacre... ;Vamos acabar con los imberbes! ‘Que se retiren de la Plaza! Porque nosotros no coincidimos con la consigna de levantar solamente banderas argentinas, levantamos la de los montoneros, porque el (Perón) intentaba diluir el movimiento de las "formaciones especiales" (a guerrilha) [...] Era una lucha de presiones en el campo político a ver quien quedaba con la conducción y había que jugar. Ahí se definía el destino de la revolución posible. viii

Apesar das pressões e ameaças exercidas, o grupo montoneros foi gradativamente perdendo espaços, aliado ao efeito intimidador das perseguições sofridas pelos seus militantes nas mãos dos grupos paramilitares da direita peronista. ${ }^{\text {ix }}$ Vendo frustradas suas aspirações, cada vez mais o grupo tenderia ao isolamento, deixando os poucos espaços políticos ainda existentes e enveredando numa política militarista e desvinculada das massas. Enquanto isso, a esquerda não peronista, o ERP, levantava a trégua que outorgara a Cámpora e retomava as operações de guerrilha.

O falecimento de Perón, em $1^{\circ}$ de julho de 1974, marcou o fim de uma época e foi um indício dos tempos difíceis que se avistavam. Pelo lado político significou a consolidação do círculo da extrema direita peronista no poder. No campo econômico, significou o fim do projeto de uma economia que priorizava a industrialização e o desenvolvimento interno e estava assentada no intervencionismo estatal. O fraco governo de Isabel Perón e seu braço direito, o ministro Lopez Rega, foi alvo constante de críticas da opinião pública. Durante o período a violência política aumentou, seja pela ação da repressão paramilitar ilegal ou pela evolução da guerrilha. Surgida nas entranhas do governo ainda enquanto Perón estava vivo, a famigerada Alianza Anticomunista Argentina (AAA), ou Tríplice A, era uma organização de repressão clandestina acobertada pelo ministério de Bem-Estar Social e comandada por Lopez Rega, ex-cabo da polícia federal convertido em ministro. Era formada por uma centena de militares e policiais aposentados ou desligados por desvios de conduta (SAENZ QUESADA, 2003, p. 273).

A Tríplice A era incapaz de combater a guerrilha, portanto, agia dedicando-se à caça de militantes sociais e praticou uma série de atentados, sequestros e assassinatos que estarreceram e comoveram a opinião pública, como o do deputado Rodolfo Ortega Peña, o professor Silvio Frondizi e o ex vice-governador de Córdoba, Atílio Lopez, entre muitos 
outros. Segundo afirma Eduardo Duhalde (1999, p. 42-43), mais de 400 homicídios teriam sido adjudicados as AAA até março de 1976. Assim, numa república formalmente democrática e teoricamente regida sob o império das leis, a ação ilegal, mas encoberta da Tríplice A, paradoxalmente instalou um permanente clima de terror e insegurança. Como ponderou um depoente:

¡Era una situación muy loca! Por un lado uno estaba en un partido político legal que tenía sede, locales, pero por otro te lo metrallaban, te lo bombardeaban, etc... Entonces, todas las organizaciones (políticas) y no solamente las de izquierda [...] comenzaron a tener guardias armadas. [...] Claro, había una diferencia enorme. ¡En Pacheco había unos cuantos compañeros armados con carabinas, revólveres, pero los tipos (das 3A) creo que derribaron la puerta con una bazuca! ¡Fue una masacre! Secuestraron a 3 compañeras y 6 compañeros. A las chicas las largaron kilómetros después, de pegarles [...] en la época todavía estos tipos tenían cierto respeto por las mujeres [...] y a los muchachos los ataron con alambre, los torturaron y fueron fusilados cerca de Pergamino. ${ }^{\mathrm{x}}$

O entrevistado, José V. se refere ao chamado "massacre de General Pacheco", quando um local pertencente ao Partido Socialista de los Trabajadores, (PST), na província de Buenos Aires, foi alvo de um ataque das AAA, um dos tantos episódios de violência paraestatal que grassaram durante o período de 1974 a 1975. Nessa época ele militava no PST. Em seu depoimento se evidencia a desigualdade existente entre os grupos de autodefesa partidários, especialmente dos que não pregavam a luta armada (caso do PST), em contraste com as armas de guerra dos paramilitares. Por último, José destacou que, apesar da brutalidade, havia ainda um "certo respeito" frente à condição feminina, algo que logo se dissiparia.

Enquanto isso, a esquerda armada acirrava a luta contra o governo, os militares e a extrema direita. A guerrilha do ERP já havia iniciado seu foco guerrilheiro na zona rural em Tucumán, enquanto os montoneros (na clandestinidade) reiniciaram suas operações guerrilheiras no meio urbano, visando estender-se em direção ao campo para estabelecer um "território liberado". A sociedade já se encontrava submersa em um clima de pânico e insegurança, onde o cotidiano da violência marcava a prática política através de atentados com bombas, sequestros, assassinatos e tiroteios nas ruas. Bruno M., antigo militante do peronismo revolucionário e que em 1975 exercia um cargo de chefia na UBA, relembra as dificuldades enfrentadas e um evento traumático deste período:

Entonces iba a dormir a casa cuando podía [...] porque todo esto me consumía tiempo (refere-se ao trabalho e a militância) $y$, en fin la seguridad también, porque a esa altura ya estaban las $3 A$ en funcionamiento [...] y por miedo a ser localizado, dormía donde la noche caía [...] Entonces los tiroteos eran casi diarios. Ahí cae Marta [...] Las 3A la fueron a buscar al hospital [...] era sicóloga y trabajaba en el hospital Lanús, [...] la sacaron arrastrándola por las escaleras y a los médicos que intentaron defenderla les dieron una paliza, a uno casi lo matan, después [...] se lo llevaron y nunca más apareció. A ella la mataron. ${ }^{x i}$

No seu depoimento evidencia-se o recrudescimento da violência ilegal paraestatal e 
como esta operava com total liberdade de ação, em locais públicos ou privados, frente a testemunhas, que podiam sofrer igual destino ao da vítima. Mas mostra também a perplexidade inicial que tomou conta dos militantes, desacostumados com esta nova modalidade repressiva. Por outro lado, se coloca a questão da disparidade de forças entre os militantes revolucionários e as forças que faziam parte da repressão clandestina. Em sua escalada, a violência repressiva passou a ser cada vez mais indiscriminada em função do caráter terrorista, abrangente e intimidador que foi adquirindo sobre o tecido social passando a atingir maiores parcelas da população.

Frente a esta profunda crise de direitos e valores inerentes a uma sociedade organizada, a tendência dos argentinos a emigrar, que havia arrefecido a partir das expectativas geradas com o retorno da democracia em 1973, retornou a ordem do dia. Durante o início do terceiro mandato peronista também se observou um acréscimo nos fluxos migratórios oriundos do Chile e do Uruguai. De fato, durante 1974 e 1975 milhares de uruguaios e chilenos saíram dos respectivos países, ambos com economias em crise e sob o influxo autoritário, esperando encontrar na promissora "Argentina Potência” de Perón novas oportunidades para uma vida digna (GARZÓN-VALDEZ, 1983).

Também é importante ressaltar que durante o interregno democrático, de 1973 a 1976, a Argentina havia concedido refúgio a diversos exilados de países vizinhos. Após o golpe no Uruguai, em julho de 1973, e a derrubada de Salvador Allende no Chile, em setembro de 1973, se intensificou também o fluxo de outros latino-americanos que haviam encontrado refúgio anteriormente naqueles países. Mas este perfil acolhedor de refugiados duraria pouco. Durante o governo da viúva de Perón, as AAA e os agentes de segurança dos regimes vizinhos, que operavam semi-clandestinamente, começaram a caçar dissidentes estrangeiros, militantes de esquerda, exilados em território argentino. ${ }^{\text {xii }}$ Pouco a pouco, o país foi se transformando numa autêntica "ratoeira" para os exilados estrangeiros, mas também para muitos argentinos que começaram a abandoná-lo cada vez em maior número, por diversos motivos, fossem eles políticos, econômicos ou uma complexa confluência de dois ou mais fatores.

Remonta ao período de 1973 a 1974 o início do fenômeno da emigração política, que se expandiria ao longo dos anos seguintes. Neste período ela ainda era pontual, ou seja, um evento geralmente circunscrito a alguns indivíduos cuja atuação ou notoriedade os tornava potenciais alvos para os grupos paramilitares. Contudo, a maior parte dos que abandonaram o país o fizeram devido à ameaça da Tríplice A e dos grupos de extrema direita. Deste modo, jornalistas, artistas, escritores, políticos, sindicalistas e muitos outros passaram ao exterior como um meio de garantir a sobrevivência. Alguns deles partiram em virtude de perseguições e ameaças concretas à própria vida ou da família, pois a AAA frequentemente enviava "avisos prévios" às vítimas. Mas muitos, sentindo-se simplesmente atemorizados, deixaram o país de forma preventiva, talvez até pressentindo que tempos piores.

Em meados de 1975, a Argentina já se encontrava à beira do colapso político e, para piorar 
a situação, afundada numa vertiginosa crise social e econômica, sob os efeitos do plano econômico conduzido por Celestino Rodrigo, novo ministro de economia. Segundo Saenz Quesada (2003, p. 298,301 ) a ortodoxia liberal da política econômica desatou na inflação e na especulação financeira, levando às famosas corridas ao dólar. A inflação atingiu patamares nunca antes observados, causando intenso mal-estar e revolta na população, especialmente nas camadas subalternas e na classe média, o qual repercutiu em espontâneos movimentos de protesto, paralisações e greves de diversos setores: desde a indústria automotiva até os professores.

Além disso, membros do impopular gabinete de Isabel apareciam envolvidos em corrupção e os serviços de informação militares colocaram em evidência, de forma oportunista, a vinculação de Lopez Rega e seu ministério com a Tríplice A, levando a sua demissão. De qualquer forma, durante 1975 e 1976 os fatores de expulsão da Argentina se potencializaram mais ainda: ao terrorismo paraestatal que instaurou o medo generalizado na sociedade, somava-se a escalada da violência guerrilheira. Em outubro de 1975 foram chanceladas pelo presidente interino Ítalo Luder, as leis anti-subversivas que deram plenos poderes às Forças Armadas para combater a guerrilha, $o$ que legitimava o acionar repressivo e outorgava carta branca aos militares para [...] aniquilar el accionar de los elementos subversivos en todo el país. (DUHALDE, 1999, p. 66). Não se desmantelou ainda a Tríplice A, mas a partir de então o controle sobre esta organização seria dos militares, e sua estrutura seria absorvida pelas forças armadas. Em Tucumán, os militares desencadearam o Operativo Independencia e procediam ao aniquilamento da guerrilha rural do PRT-ERP, sem se preocupar com procedimentos legais ou códigos de ética. Desta forma, a união entre as três armas se deu em função da luta anti-subversiva, pois cada força tinha seus interesses particulares, posicionamentos ideológicos e vinculações políticas díspares, mas a argamassa que as unia era o anticomunismo, fundamento da DSN.

Evidenciava-se no país o agravamento dos problemas no cenário político, econômico e social. A presidente Isabel Perón, sem o suporte do conselheiro Lopez Rega, estava cada vez mais isolada. O seu governo era frágil e inoperante frente aos desafios apresentados. A essa altura, empresários, militares e partidos políticos estavam envolvidos em disputas intersticiais pela partilha e controle do poder Estatal, negociando entre si o espólio futuro de um Estado democrático agonizante.

Impacientes, setores ultranacionalistas da Força Aérea se insurgiram em dezembro de 1975, pedindo simultaneamente a renúncia do comandante da Força Aérea, da presidente e propondo que o comandante em chefe do exército Videla assumisse a presidência. Embora fracassada no intento de derrubar a presidente, a sublevação serviu para evidenciar as debilidades do governo e sua incapacidade de negociar uma saída constitucional para a crise política. Um artigo na revista Gente ponderava que, frente à debilidade da classe política no evento, destacava-se o profissionalismo legalista dos comandantes do exército e da marinha, cuja lealdade às instituições democráticas havia sido posta a prova num momento limite. 
[...] y otro el plano nacional. Aqui dio a entender que confiaba de las "instituciones" rápidos remedios para la crisis. [...] La que ha salido, pues, fortalecida de esta crisis es la autoridad de dos comandantes generales. ${ }^{\text {xiii }}$

Grupos mediáticos contribuíam a desprestigiar o governo e as instituições políticas em geral e, concomitantemente, construíam por oposição uma imagem positiva das forças armadas para a população. Os militares eram apresentados como paladinos da lei e da ordem, os únicos capazes de salvaguardar a nação da crise, da subversão e da corrupção. Além de aumentar o prestígio dos militares, a manobra golpista também serviu para aumentar a coesão militar e unificar os objetivos das três forças armadas, assim como para "sincronizar o relógio" dos golpistas. Apenas alguns dias depois da tentativa insurrecional, quase na véspera de Natal, o governo receberia outra manobra desestabilizadora, desta vez das mãos da guerrilha. Um comando composto por uma centena de militantes do ERP intentou ocupar o arsenal do exército na região de Monte Chingolo, próximo a Buenos Aires.

O objetivo dos atacantes era apropriar-se de uma grande quantidade de armas para abastecer a guerrilha. No entanto, o efeito surpresa, indispensável para a operação, fracassou em virtude de o ERP estar infiltrado pelo inimigo (RAGENDORFER, 2016). Os militares tinham pleno conhecimento do ataque, que se revelou uma armadilha mortal para os guerrilheiros. Estes foram caçados e eliminados por um impressionante aparato militar das forças armadas e as polícias. Contudo, conforme afirmam Anguita e Caparrós (p. 475), nunca houve um registro preciso das mortes de Monte Chingolo, mas a quantidade oscilava entre 90 e 165 pessoas, e a repressão indiscriminada atingiu inclusive moradores vizinhos da base. O ERP nunca se recuperou desse impacto.

Andréa, professora universitária e militante do PRT que instruía politicamente os quadros combatentes do ERP, pode sentir naquele momento a baixa moral de combate e o pessimismo grassando entre os militantes:

En 1975 a mi me pasan a una escuela de cuadros políticos [...] y ahí en contacto con los cuadros te das cuenta que el asunto estaba difícil. Entonces la política era que si había

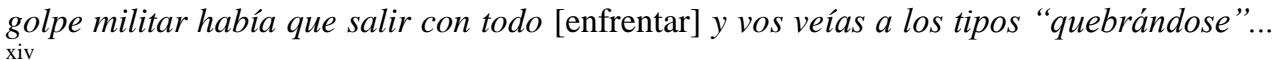

Considerou que o partido estava descolado da realidade e absorvido exclusivamente pela ótica militarista em detrimento da luta de massas, encaminhando-se ao que considerou uma "política suicida". A sua discordância com a linha do partido a levou a pedir o seu desligamento, um processo complexo e repleto de contradições, permeado pelo peso emocional que implica a ruptura com o compromisso de um projeto político que pretendia mudar a estrutura social, e o sentimento de culpa ao sentir que abandonava a luta a qual havia dedicado anos.

Para os militares, a relativamente fácil derrota da guerrilha demonstrou a impotência da mesma no plano militar. Logo, o perigo da tomada do poder por parte da guerrilha estava descartado (SAENZ QUESADA, 2003, p. 391). Os militares, que até pouco haviam sido meros espectadores do caos, colocavam-se como protagonistas. No discurso de Natal do comandante do exército, general Videla, se impunha a governante um prazo de 90 dias para colocar o "país no rumo" desejado. 
As diversas saídas institucionais propostas para a crise política, tais como a renúncia ou destituição da presidente via impeachment, esbarraram na falta de respaldo mútuo entre os diversos setores políticos, mais preocupados com seus interesses do que com a democracia. No início de 1976 a situação geral na Argentina era desesperadora. Por esses dias, o jornal gaúcho Zero Hora, que dedicava boa parte da sua seção "Mundo" à crise Argentina e que reproduzia para seus leitores as informações colhidas in loco ou veiculadas pelas agências internacionais, noticiou que:

(...) prosseguiam os sequestros, atentados terroristas e a agitação operária em vários pontos do país, ante a crescente crise da situação econômica, traduzida numa inflação de $423 \%$ (...) e na carestia de gêneros de primeira necessidade e consumo, cujos preços subiram vertiginosamente. ${ }^{x v}$

De fato, evidenciava-se o fracasso do mais recente plano econômico de Emilio Mondelli, que pretendia controlar a inflação, mediante o congelamento de preços e salários. O empréstimo com o Fundo Monetário Internacional (FMI) mal alcançaria para pagar os compromissos, colocando o país à beira da insolvência. ${ }^{\text {xvi }}$ Paralelamente, os setores corporativos patronais já haviam pactuado alianças com os militares, avalizando o caminho para o golpe. O colapso político e econômico se traduziu em um substancial aumento do fluxo migratório em direção ao exterior, já em marcha. Neste cenário de "final dos tempos" em que se encontrava a Argentina, milhares de pessoas encontravam nos aeroportos e estações rodoviárias e ferroviárias a única saída plausível para a crise do país: abandoná-lo.

\section{Epílogo}

Na madrugada do dia 24 de março de 1976, uma junta militar das Forças Armadas depôs a viúva de Perón. Uma proclama radial anunciou o fato à população ordenando o acatamento das diretivas emanadas do poder militar. Um dia depois, além de louvar o golpe numa edição especial, a revista Gente ${ }^{x v i i}$ ofereceu a seus leitores um "valioso documento" intitulado Dramática Crónica de los 1035 dias del Peronismo, uma demonização das várias etapas da administração peronista e que culminava com a "redentora" ação militar. Cansada da violência, da insegurança e da instabilidade, uma grande parte da sociedade argentina, totalmente descrente da democracia, foi novamente convencida de que o golpe era tão inevitável quanto necessário.

\section{Referências}

ANGUITA, E.; CAPARRÓS, M. La voluntad. Una historia de la militancia revolucionaria en Argentina. V Tomos, Buenos Aires: Booket, 2006. 
DUHALDE, E. L. El Estado terrorista argentino. Quince años después, una mirada crítica. Buenos Aires: Eudeba, 1999.

GARZÓN -VALDÉZ, E. La emigración argentina. Acerca de sus causas ético-políticas. In: WALDMANN, P.; GARZÓN - VALDÉZ, E. (comp.) El poder militar en la Argentina, 1976-1981. Buenos Aires: Galerna, 1983.

GASPARINI, J. Montoneros, final de cuentas. La Plata: De la Campana, 2005.

GILLESPIE, R. Soldados de Perón: los Montoneros. Buenos Aires: Grijalbo, 1998.

LATTES, A.; OTEIZA, E. (eds.). Dinámica migratoria argentina (1955-1984) Democratización y retorno de los expatriados. Tomo I y II. Buenos Aires, CEAL, 1987.

PIGNA, F.; SEOANE, M. La noche de la dictadura: memoria fotográfica inédita a 30 anos del terror. Buenos Aires, Fundación Octubre, 2006.

POLLAK, M. "Memória e identidade social”. In: Estudos Históricos. Rio de Janeiro, v. 5, n. 10, 1992, p. 200-212.

DE RIZ, L. La Política en Suspenso 1966/1976. Buenos Aires: Paidós, 2000.

ROMERO, L. A. Breve história contemporánea de la Argentina: 1916-1999. BsAs: Fondo de Cultura Económica, 2004.

SAENZ QUESADA, M. Isabel Perón: La Argentina en los años de Maria Estela Martinez. Buenos Aires: Planeta, 2003.

ZUCCOTTI, J. C. La Emigración Argentina Contemporánea (a partir de 1950). Buenos Aires: Editorial Plus Ultra, 1987.

RAGENDORFER, R. Los doblados. Infiltraciones del Batallón 601 en la guerrilla argentina. Buenos Aires: Sudamericana, 2016. 
Recebido: 15/06/2019

Aceito: 08/07/2019

Publicado: 04/09/2019

\section{Notas}

\footnotetext{
${ }^{\text {i }}$ Doutor em História pela Universidade Federal do Rio Grande do Sul. Leciona na Universidade Federal de Mato Grosso do Sul. E-mail: intbrig@yahoo.com.br

ii Entrevista com F. K., Porto Alegre, 29/06/2007.

iii Entrevista com A. T., Porto Alegre, 01/04/2008.

iv Idem.

${ }^{v}$ Idem.

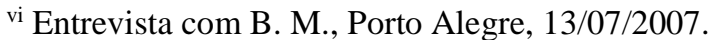

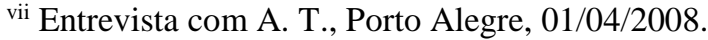

viii Entrevista com B. M., Porto Alegre, 13/07/2007.

ix Além das AAA, agiam diversos grupos armados de extrema direita, ligados ao peronismo ortodoxo ou aos nacionalistas de corte fascista: o Comando de Organización (CdeO), o Comando Nacional Universitário (CNU), a Juventud Peronista de la República Argentina (JPRA).

${ }^{x}$ Entrevista com J.V., Porto Alegre, 20/06/2007.

${ }^{x i}$ Entrevista com B. M., Porto Alegre, 13/07/2007.

xii Segundo a Comissão de Mortos e Desaparecidos Políticos oito cidadãos brasileiros desapareceram na Argentina entre 1975 - 1980.

xiii Gente, 25/12/1975, p.18.

xiv Entrevista com A. T., Porto Alegre, 01/04/2008 - Quebrado significava desmoralizado, no jargão da guerrilha.

${ }^{\mathrm{xv}}$ Zero Hora, 23/03/1976, p. 14.

xvi Idem.

xvii Gente, 25/03/1976, p. 16 e 70-75.
} 